\title{
Capsaicin reduces genotoxicity, colonic cell proliferation and preneoplastic lesions induced by 1,2-dimethylhydrazine in rats
}

\author{
Brunno Felipe Ramos Caetano ${ }^{\mathrm{a}}$, Mariana Baptista Tablas ${ }^{\mathrm{b}}$, Natália Elias Ferreira Pereira ${ }^{\mathrm{b}}$, \\ Nelci Antunes de Moura ${ }^{\mathrm{b}}$, Robson Francisco Carvalho ${ }^{\mathrm{b}}$, Maria Aparecida Marchesan Rodrigues ${ }^{\mathrm{a}}$, \\ Luis Fernando Barbisan ${ }^{\mathrm{b}, *}$
}

${ }^{a}$ Department of Pathology, Medical School, São Paulo State University (UNESP), Botucatu, 18618-687, Brazil

${ }^{\mathrm{b}}$ Department of Morphology, Institute of Biosciences, São Paulo State University (UNESP), Botucatu, 18618-689, Brazil

\section{A R T I C L E I N F O}

\section{Keywords:}

Capsaicin

Colon Cancer

Chemoprevention

\begin{abstract}
A B S T R A C T
Capsaicin (8-Methyl-N-vanillyl-(trans)-6-nonenamide) is the major pungent ingredient found in chili peppers consumed worldwide. Most reports on capsaicin potential carcinogenicity have yielded inconsistent findings. Some studies have shown that capsaicin exerts anti-proliferative and pro-apoptotic effects on different cancer cell lines, while others have reported an association between capsaicin at high doses with mutagenicity and carcinogenicity. Thus, this study aimed at assessing the effects of capsaicin administration on 1,2-dimethylhydrazine (DMH)-induced colon carcinogenesis in male Wistar rats. Our results show that capsaicin administration, before and during carcinogen exposure, modified DMH-induced cytotoxicity and genotoxicity, promoting anti-proliferative and pro-apoptotic responses through the expression of the genes involved in apoptosis, cell cycle suppression and cell/tissue differentiation. Furthermore, capsaicin reduced aberrant crypt foci (ACF) number and multiplicity, although there were no differences in tumor incidence and multiplicity among the groups. Taken together, the results suggest that capsaicin may have a preventive effect against DMH-induced colorectal carcinogenesis.
\end{abstract}

\section{Introduction}

Colorectal cancer (CRC) is the third most common type of cancer, and a leading cause of death worldwide (Torre et al. 2015). World Health Organization (WHO) GLOBOCAN estimates for 2015 showed that CRC burden represents up to $9.7 \%$ of all incident malignancies, accounting for 746,000 new cases in men and 614,000 in women (Ferlay et al. 2015). The incidence and mortality rates of CRC vary greatly across the world (Kamangar et al. 2006). However, CRC more frequently occurs in developed countries, indicating a correlation with western dietary habits and lifestyle patterns, such as smoking, alcohol consumption, obesity and physical inactivity (Gingras and Béliveau 2011). These are known risk factors that are potentially modifiable and avoidable through specific public strategies for cancer prevention. Reducing consumption of refined starches, saturated fat, and processed or red meat, as well as increasing the intake of fruits and vegetables has been associated with lower CRC risk (Carr et al. 2016; Dahham and Majid 2016).

Natural anticancer bioactive compounds have been lately acknowledged with great public enthusiasm. Indeed, several bioactive compounds found in vegetables and medicinal plants can reduce the risk of developing chronic diseases such as cancer (Sales et al. 2014). Fruits and vegetables play an essential role in human nutrition and health, providing natural fibers, antioxidants, and a broad range of bioactive phytochemicals (Liu 2013). Evidence from many pre-clinical and clinical studies support that dietary interventions stand as a promising strategy for CRC prevention (Baena and Salinas 2015; Hou et al. 2013).

Capsaicin (8-methyl-N-vanillyl-trans-6-nonenamide) is the major pungent alkaloid ingredient found in chili peppers (Bosland et al. 2012). The chili pepper is the fruit of herbaceous plants of the genus Capsicum, members of the family Solanacea, native to the Americas. Chilies have long been domesticated by Mesoamerican civilizations and are appreciated worldwide for both culinary and medicinal purposes (Heiser and Smith 1953). In fact, chili peppers represent a fair amount of total vegetables daily consumed around the world (Kantar et al. 2016). Capsaicin has emerged as a potential therapeutic drug to treat a number of human diseases, including chronic pain, obesity, diabetes, cardiovascular conditions, airway diseases and cancer (Fattori et al. 2016).

\footnotetext{
* Corresponding author at: Rua Prof. Dr. Antonio Celso Wagner Zanin s/n, 18618-689, Botucatu, SP, Brazil.

E-mail address: barbisan@ibb.unesp.br (L.F. Barbisan).
} 
Scientific reports on capsaicin potential carcinogenicity have yielded inconsistent findings (Bode and Dong 2011). Some studies have shown that capsaicin exerts anti-proliferative and pro-apoptotic effects on different cancer cell lines (Brown et al. 2010; Díaz-Laviada 2010; Garufi et al. 2016; Lau et al. 2014) and might inhibit the metabolism of chemical carcinogens by interacting with a number of cytochrome P450 enzymes (CYPs) (Zhang et al. 2012). On the other hand, Lee and Park have reported an association between capsaicin at high doses with mutagenicity and carcinogenicity (Lee and Park 2003). Furthermore, several preclinical studies have suggested that the chili extract or capsaicin alone can have co-carcinogenic effects on the stomach, liver, colon and skin in different chemically-induced carcinogenesis models (Agrawal et al. 1986; Díaz Barriga Arceo et al. 1995; Johnson 2007; Liu et al. 2015). Considering that the molecular mechanisms underlying the putative effects of capsaicin on colon carcinogenesis are largely unknown, this study aimed at assessing the effects of capsaicin oral administration on DNA damage, cell proliferation, and apoptosis, as well as on the expression of the genes involved in oxidative metabolism, antioxidant activity, cell cycle, DNA repair and cell death pathways during the early stages of colon carcinogenesis induced by 1,2-dimethylhydrazine $(\mathrm{DMH})$ in rats.

\section{Material and methods}

\section{1. - Chemicals}

Capsaicin (8-methyl-N-vanillyl-trans-6-nonenamide, purity $\geq 95 \%$, PubChem CID:1,548,943) and DMH (1,2-dimethylhydrazine hydrochloride, PubChem CID: 1322) were purchased from Sigma-Aldrich (Darmstadt, Germany). All other reagents were of the highest grade available commercially.

\section{2. - Study design}

Four-week-old male Wistar rats weighing $125 \mathrm{~g}$ (ANILAB, Paulínia$\mathrm{SP}$, Brazil) were housed in polypropylene cages under standard conditions $\left(21 \pm 2{ }^{\circ} \mathrm{C}\right.$ temperature, $55 \pm 10 \%$ humidity, and $12 \mathrm{~h} / 12 \mathrm{~h}$ light-dark cycle) with food (NUVILAB-CR-1, Curitiba, Brazil) and tap water ad libitum. The animals used in this study were handled in accordance with the principles of laboratory animal care adopted by the Brazilian College of Animal Experimentation (COBEA). This study was approved by the institution's Ethics Review Board (1153/2015-CEUA).

After a 3-week acclimation period, the animals (7-week old) were randomly assigned into six experimental groups with 16 animals each. Intragastric doses of corn oil (capsaicin vehicle, G1 and G6), capsaicin at $5 \mathrm{mg} / \mathrm{kg}$ body weight (bw) (G2 and G4) and $50 \mathrm{mg} / \mathrm{kg}$ bw (G3 and G5) were administered three times a week for four weeks. The capsaicin dosages used were determined based on previous reports (Saito and Yamamoto 1996). Either a subcutaneous injection of DMH (G1, G2 and $\mathrm{G} 3,40 \mathrm{mg} / \mathrm{kg}$ bw) or disodium ethylenediamine tetraacetic acid ( $\mathrm{Na}_{2}$ EDTA, DMH vehicle, G4, G5 and G6) was given twice a week over weeks 3 and 4. DMH was dissolved in $1 \mathrm{mM} \mathrm{Na} \mathrm{N}_{2}$ EDTA in order to ensure stability (Rubio 2017). Body weight and food consumption were recorded weekly throughout the experiment. By the end of week 4, 6 animals from each group were sacrificed (short-term assays, $n=6$ ). The remaining animals were sacrificed at 22 weeks (mid-term assays, $n=10$ ) (Fig. 1).

\subsection{Short-term assays}

\section{Leukocyte genotoxicity.}

Capsaicin anti-genotoxic potential was assessed in peripheral blood leukocytes $24 \mathrm{~h}$ after the last DMH injection using the single cell gel electrophoresis (comet) assay under alkaline conditions as previously described (Nandhakumar et al. 2011). Peripheral blood samples, collected by retroorbital venipuncture, were mixed with $100 \mu \mathrm{L}$ of low melting point agarose $(0.75 \%$ in PBS, Invitrogen, USA.), spread on slides pre-coated with normal point agarose (1.5\% in PBS, Invitrogen, USA), and coverslipped. Following agarose solidification $\left(4{ }^{\circ} \mathrm{C}\right.$ for $10 \mathrm{~min}$ ), coverslips were carefully removed and the slides were incubated with cold lysis solution $\left(2.5 \mathrm{M} \mathrm{NaCl}, 100 \mathrm{mM} \mathrm{Na}{ }_{2}\right.$ EDTA, $10 \mathrm{mM}$ Tris- $\mathrm{HCl}, 1 \%$ sarkosyl, $\mathrm{pH} 10$ ) overnight, at $4{ }^{\circ} \mathrm{C}$. Subsequently, the slides were washed three times in PBS and immersed in fresh cold alkaline electrophoresis buffer $\left(300 \mathrm{mM} \mathrm{NaOH}, 1 \mathrm{mM} \mathrm{Na} \mathrm{N}_{2}\right.$ EDTA, $\mathrm{pH}>13$ ) for $20 \mathrm{~min}$. Electrophoresis was conducted at a room temperature of $21{ }^{\circ} \mathrm{C}$ for $20 \mathrm{~min}$ at $1 \mathrm{~V} / \mathrm{cm}(300 \mathrm{~mA})$ for $20 \mathrm{~min}$. The slides were then neutralized with $0.4 \mathrm{M}$ Tris ( $\mathrm{pH} 7.5$ ), dehydrated in $100 \%$ ethanol, and stained with Sybr Gold (Invitrogen, USA). An epi-fluorescence microscope (Olympus BX-50, Japan) coupled to a CCD camera was used to score fifty random nucleoid/sample using the Comet Assay IV Image Analysis System (Perceptive Instruments, UK). All experiments were performed in duplicate.

Fecal water genotoxicity.

Cecal feces were collected at sacrifice and kept frozen at $-20{ }^{\circ} \mathrm{C}$ prior to use. Fecal water was prepared as described elsewhere (Klinder et al. 2007) with minor modifications. Briefly, fecal slurry was prepared by mixing feces with ice-cold PBS at a 1:1 rate $(1 \mathrm{~g}$ of fecal content $+1 \mathrm{~mL}$ of PBS). This mixture was homogenized for $3 \mathrm{~min}$. Fecal debris were removed by centrifuging homogenates at $35,000 \mathrm{~g}$ for $30 \mathrm{~min}$. The supernatant was filtered with an $\emptyset 0.22 \mu \mathrm{M}$ sterile filter unit (Millipore, Germany), aliquoted and frozen until analysis.

Caco-2 (human colon adenocarcinoma) cells were obtained from the Rio de Janeiro Cell Bank (BCRJ, Brazil) and grown in $75-\mathrm{cm}^{2}$ culture flasks with DMEM high-glucose medium supplemented with $10 \%$ fetal bovine serum, $0.1 \mathrm{nM}$ non-essential amino acids, $50 \mu \mathrm{g} / \mathrm{mL}$ streptomycin, in a humid $5 \% \mathrm{CO}_{2}$ atmosphere at $37{ }^{\circ} \mathrm{C}$. CaCO- 2 cells between passages 38 and 39 were used in the analysis of fecal water genotoxicity. Upon reaching confluence, cells were harvested with Accutase cell detachment solution (Sigma Aldrich, USA), split into 1-mL centrifuged tubes and spun at $1200 \mathrm{~g}$ for $1 \mathrm{~min}$. The supernatant was removed and cells were directly incubated with $100 \%$ fecal water at $37{ }^{\circ} \mathrm{C}$ for $30 \mathrm{~min}$. Cell viability was determined by the trypan blue exclusion assay. The remaining cell pellet was then mixed with $100 \mu \mathrm{L}$ of low melting point agarose $(0.75 \%$ in $\mathrm{PBS})$, spread on slides pre-coated with normal point agarose (1.5\% in PBS), and coverslipped. Fecal water genotoxicity in CaCO-2 cells was determined by the comet assay as described above.

Serum biochemistry and tissue collection.

Six animals from each group were sacrificed $24 \mathrm{~h}$ after the last DMH injection. Blood samples were collected by cardiac puncture under xylazine and ketamine anesthesia $(10 \mathrm{mg} / \mathrm{kg}$ and $80 \mathrm{mg} / \mathrm{kg}$ bw, respectively). Serum alanine aminotransferase (ALT) and aspartate aminotransferase (AST) activity was determined using the COBAS 6000 (Roche Diagnostics, USA) with commercial kits. After laparotomy, colon and liver tissue fragments were collected and either stored at $-80{ }^{\circ} \mathrm{C}$ for RNA extraction, or fixed in $4 \%$ buffered formalin and stored in $70 \%$ ethanol for histopathology and immunohistochemistry analyses.

Immunohistochemistry analysis.

Paraffin-embedded 5- $\mu$ m-thick colon sections were deparaffinized and rehydrated in a graded xylene-alcohol series. Antigen retrieval was performed using a $10 \mathrm{nM}$ sodium citrate buffer solution by pressurecooker heating (Pascal, Dako). Endogenous peroxidase was quenched with $10 \%$ hydrogen peroxide solution for $10 \mathrm{~min}$. Tissues sections were incubated with blocking solution (7\% skimmed milk in PBS) for $1 \mathrm{~h}$ and then immunostained overnight with primary antibodies for Ki-67 (Abcam no. 15580) and active Caspase-3 (Abcam no. ab2302). Sections were washed three times in PBS and incubated with one-step universal HRP polymer (Easy Path, USA) for 25 min. Tissue sections were stained for 5 min using DAB as chromogen and counter-stained with Harry's hematoxylin for $1 \mathrm{~min}$. Six rats from each group were analyzed and 25 crypts were scored per animal. Ki-67 and active Caspase-3 labeling indexes (LI) were scored by the number of positive-stained cells/ number of cells per crypt ratio. 

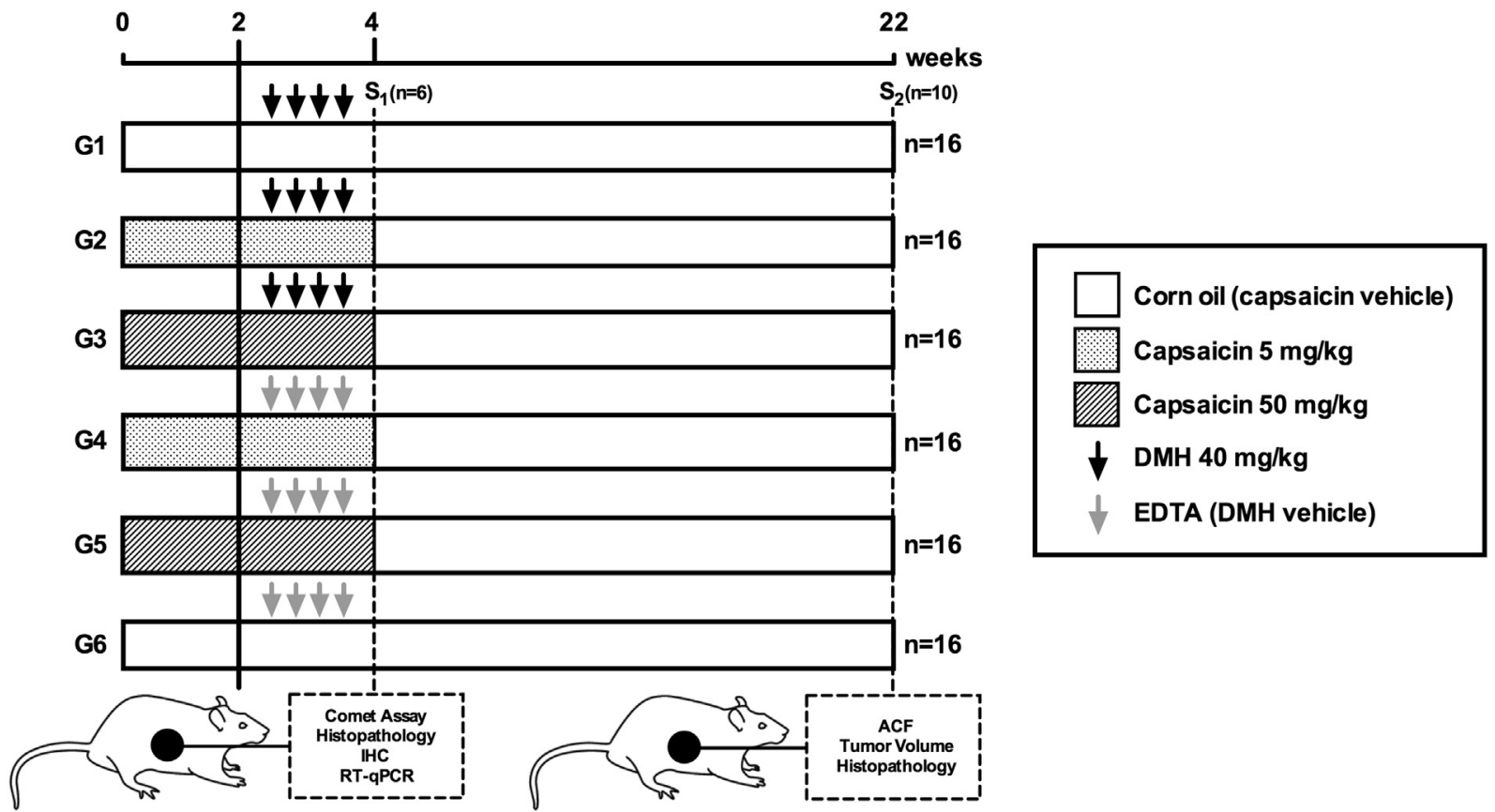

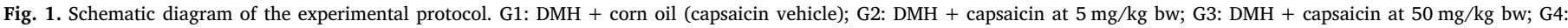

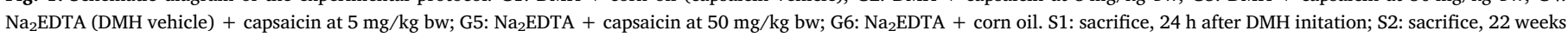
after DMH initiation; DMH: 1,2-dimethylhidrazine; $\mathrm{Na}_{2}$ EDTA: disodium ethylenediamine tetraacetic acid; IHC: immunohistochemistry; ACF: aberrant crypt foci.

RNA isolation and reverse transcription.

Total RNA was extracted from frozen colon and liver samples using the Rneasy Mini kit (Qiagen, Hilden, Germany). Following on-column DNA digestion, RNA samples were solubilized in nuclease-free water (Qiagen, Hilden, Germany). RNA concentration and integrity were evaluated by spectrophotometry (NanoVue ${ }^{\mathrm{TM}}$ Plus, GE Healthcare BioSciences Corp, Piscataway, NJ, EUA) and capillary electrophoresis (Agilent 2100 bioanalyzer, Agilent Technologies, Boeblingen, Germany), respectively. Total RNA (60 ng/ $\mu \mathrm{l})$ was reverse-transcribed to first-strand cDNA using SuperScript IV First Strand SuperMix (Invitrogen $^{\mathrm{TM}}$, Life Tech, USA) according to the manufacturer's instruction.

Quantitative real-time PCR.

RNA expression assessment was performed using a 96-well TaqMan ${ }^{\circledast}$ Array Cards (TAC)-based real-time polymerase chain reaction (PCR). A total of 96 genes involved in the oxidative metabolism, proand antioxidant activity, cell proliferation, DNA damage, DNA repair and apoptosis were assessed (Supplementary Material, SM1 and SM2). $\beta$-Actin, Gapdh, Gusb and Hprt1 were used as housekeeping genes to normalize mRNA expression. Target genes were amplified with TaqMan ${ }^{\circledR}$ Universal Mastermix II (Life Technologies, USA) using the following cycling protocol: heat activation at $50{ }^{\circ} \mathrm{C}$ for $1 \mathrm{~min}$ and denaturation at $95^{\circ} \mathrm{C}$ for $10 \mathrm{~min}$ followed by 40 cycles $\left(95^{\circ} \mathrm{C}\right.$ for $15 \mathrm{~s}$ and $60^{\circ} \mathrm{C}$ for $\left.1 \mathrm{~min}\right)$. Fluorescence was detected using the QuantStudio ${ }^{\mathrm{TM}}$ 12 K Flex Real-Time PCR System (Life Technologies, USA). The relative expression of target genes was analyzed by the comparative Ct method (ExpressionSuite $^{\mathrm{TM}}$ software, Life Technologies, USA). Functional enrichment analysis was conducted using the Gene Ontology annotation tool (Ashburner et al. 2000). This study was conducted according to the MIQE (Minimum Information for Publication of Quantitative Real-Time PCR experiments) guidelines (Bustin et al. 2009).

\section{4. - Mid-term assays}

Tumor volume and histopathology.

Ten animals from each group were sacrificed 22 weeks after the last $\mathrm{DMH}$ administration. Colon specimens were removed, opened longitudinally, and pinned flat. The specimens were fixed in $10 \%$ phosphate-buffered formalin for $24 \mathrm{~h}$ and kept in ethanol $70 \%$ prior to analysis. Macroscopic tumors were counted, removed, and measured $e x$ vivo using a digital caliper. Tumor volumes were calculated using the following prolate spheroid formula: $4 / 3 \times 3.14 \mathrm{x}$ (length/2) $\mathrm{x}$ (width/ 2) $x$ (depth/2) (Schiavon et al. 2012). Colon specimens were paraffin embedded and sectioned for histopathological analysis. Adenocarcinomas were classified into invasive (tubular or mucinous) or non-invasive (carcinoma in situ) according to the International Harmonization of Nomenclature and Diagnostic Criteria for Lesions in Rats and Mice (Nolte et al. 2016).

Identification and quantification of ACF.

Aberrant crypt foci (ACF) pre-neoplastic lesions were identified in formalin-fixed colon specimens (proximal, medial and distal) stained with $0.2 \%$ methylene blue. The total number of ACF and the number of aberrant crypts (AC) were counted under light microscopy. The ACF were identified topographically according to Bird's morphological criteria (Bird 1987): (i) increased size; (ii) thickened epithelial cell lining; (iii) increased pericryptal space and (iv) irregular lumens. Since ACF size is closely related to the risk of developing colon tumors, ACF were divided into 3 categories: 1-3 crypts/focus, $4-8$ crypts/focus and $\geq 9$ crypts/focus (Corpet and Taché 2002).

\section{5. - Statistical analysis}

Data were statistically evaluated using the Prism v6 software (GraphPad). One-way ANOVA analysis followed by post hoc Tukey's test was used to compare groups. Fisher's exact test was used to compare tumor incidence and histopathological categories. To identify significant differences in gene expression, normalized expression means were compared using Student's $t$-test. Significance was set at $p<0.05$.

\section{Results}

\section{1. - Short-term assays}

Leukocyte and fecal water genotoxicity. 

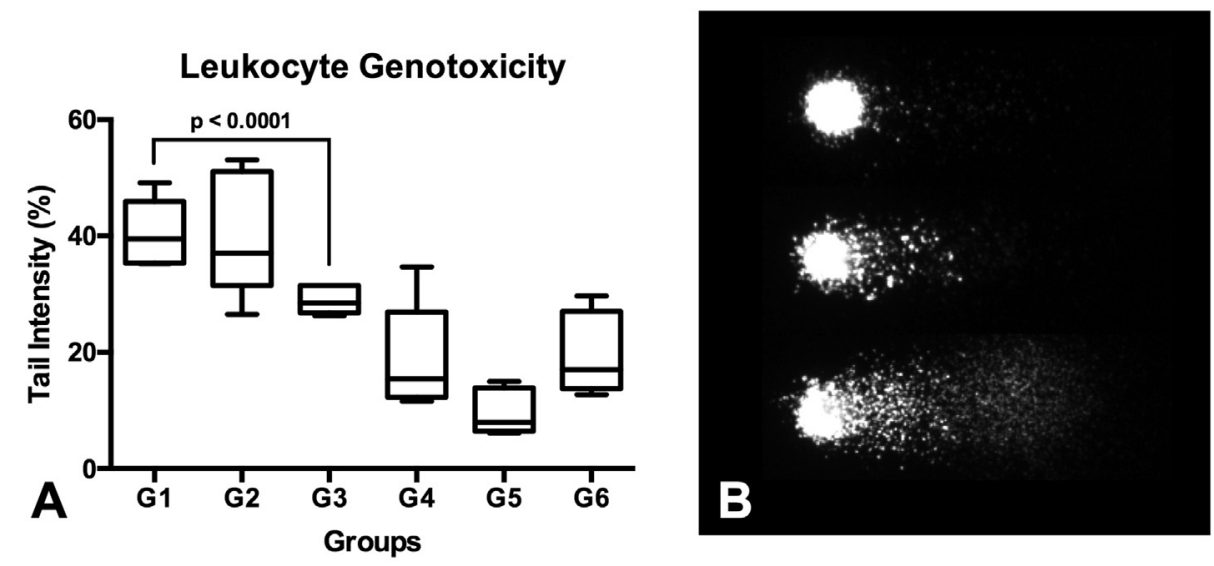

Figure 2. Detection of DNA damage by the comet assay ${ }^{1}$. (A) Suppressing effects of capsaicin administration on DMH-induced genotoxicity in peripheral blood leukocytes. (B) Representative comet images showing different levels of DNA damage in peripheral blood leukocytes. (C) Suppressing effects of capsaicin administration on DMHinduced fecal water genotoxicity in CaCO-2 tumor cells. (D) Representative comet images showing different levels of DNA damage in CaCO-2 cells. ${ }^{1}$ Data are presented as box plot with median and interquartile ranges, compared by One-way ANOVA followed by post hoc Tukey's test. G1: $\mathrm{DMH}+$ corn oil (capsaicin vehicle); G2: DMH + capsaicin at $5 \mathrm{mg} / \mathrm{kg}$ bw; G3: DMH + capsaicin at $50 \mathrm{mg} / \mathrm{kg}$ bw; G4: $\mathrm{Na}_{2}$ EDTA (DMH vehicle) + capsaicin at $5 \mathrm{mg} / \mathrm{kg}$ bw; G5: $\mathrm{Na}_{2} \mathrm{EDTA}+$ capsaicin at $50 \mathrm{mg} / \mathrm{kg}$ bw; G6: $\mathrm{Na}_{2}$ EDTA + corn oil. S: sacrifice; DMH: 1,2-dimethylhidrazine; $\mathrm{Na}_{2}$ EDTA: disodium ethylenediamine tetraacetic acid.
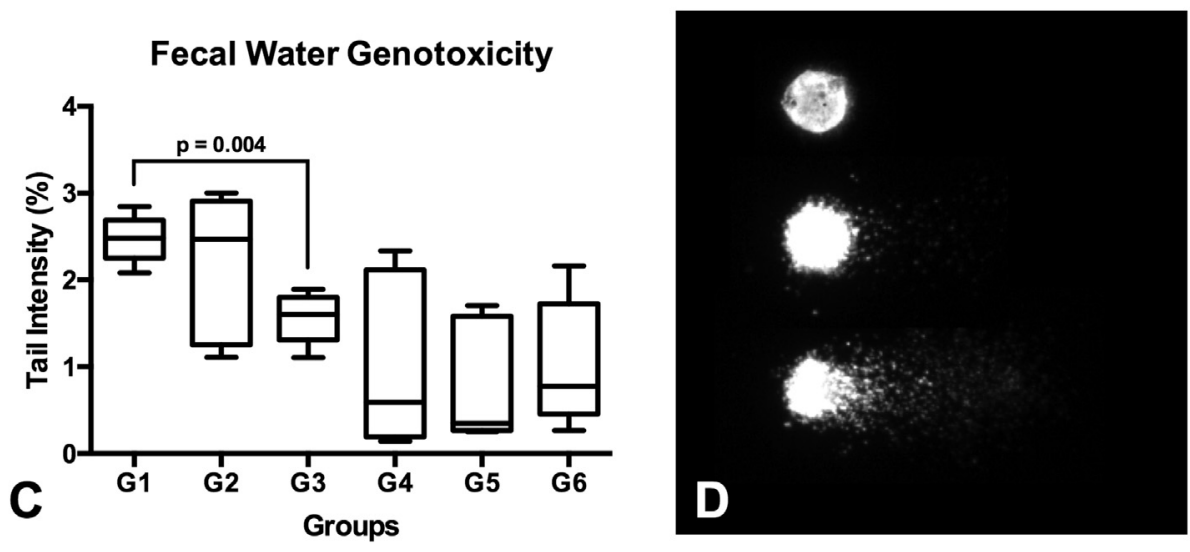

Fig. 2 (A and B) shows the levels of DNA damage in peripheral blood leukocytes from all groups. DNA damage levels were significantly higher in the DMH-treated groups (G1-G3) than in their respective control groups (G4-G6) ( $p=0.0001)$. DMH-induced genotoxicity was significantly reduced in the group receiving capsaicin at $50 \mathrm{mg} / \mathrm{kg}$ (G3) when compared to other DMH-treated groups (G1 and G2) $(p=0.0001)$. Capsaicin treatment per se (G5 and G6) did not induce DNA damage in comparison to the control group (G6).

Fig. 2 (C and D) shows the effects of capsaicin oral administration on fecal water genotoxicity in all groups. CaCO-2 cell viability remained unchanged after exposure to fecal water from the DMH-treated and control groups (data not shown). Fecal water genotoxicity was significantly higher in the DMH-treated groups (G1-G3) than in their respective controls $(\mathrm{G} 4-\mathrm{G} 6)(p=0.004)$. DMH-induced fecal water genotoxicity was significantly reduced by capsaicin at $50 \mathrm{mg} / \mathrm{kg}$ (G3) $(p=0.004)$. Fecal water genotoxicity levels in capsaicin at 5 and $50 \mathrm{mg} / \mathrm{kg}$ groups (G4 and G5) remained similar to the control group (G6).

Body weight, liver weight, food intake, biochemical and histopathological analyses.

Table 1 shows body weight, liver weight and serum biochemical parameters in all groups at weeks 4 and 22. No differences in body weight and relative liver weight were found among the groups by the end of weeks 4 and 22 (Table 1). Over the first four weeks, there was a significant elevation in ALT and AST serum levels in the DMH-treated groups (G1-G3) $(p<0.0005)$. No differences in food intake and liver relative weight were observed among groups. In the DMH-treated groups (G1-G3), the colonic mucosa showed toxic lesions characterized by crypt distortions, depletion of goblet cells and increased apoptosis (Fig. 3A). Capsaicin oral administration alone (G4 and G5) did not induce colonic toxicity when compared to the control group (G6) (Fig. 3B).
Ki-67 and active caspase-3 labeling indexes.

As shown in Fig. 3C, Ki-67 proliferation index was significantly reduced $(20 \%)$ with capsaicin at $50 \mathrm{mg} / \mathrm{kg}(\mathrm{G} 3)(p=0.0001)$ when compared to DMH-treated groups (G1 and G2). Caspase-3 labeling indexes were similar among groups (Fig. 3D).

Differential gene expression evaluation.

Table 2 compares differential gene expression in colonic mucosa from the capsaicin-treated (G2 to G5) and control groups (G1 and G6). Three genes were differentially expressed in both groups receiving capsaicin $5 \mathrm{mg} / \mathrm{kg}$ (G2 and G4, Table 4) when compared to control groups (G1 and G6). Capsaicin at $50 \mathrm{mg} / \mathrm{kg}$ (G3) also induced the differential expression of 15 genes on colonic mucosa from the DMHtreated group (Table 2). Functional enrichment analysis demonstrated that these upregulated genes belong to functional categories involved in the adaptive response to chemicals, as well as apoptosis and tissue development (Table 3). No genes were found to be differentially expressed in the liver in all groups (Supplementary Material, SM3 and SM4).

\section{2. - Mid-term assays}

Tumor volume and histopathological analysis.

In group receiving capsaicin at $50 \mathrm{mg} / \mathrm{kg}$, (G3) the rate of small tumors (35\%) was higher than those in the DMH-treated groups (G1, G2), but the statistical difference among groups was not significant (Fig. 4A and B). The average tumor volume was $105 \mathrm{~mm}^{3}$ in DMHtreated group (G1) whereas in the groups receiving capsaicin at 5 and $50 \mathrm{mg} / \mathrm{kg}$ (G2 and G3) it was 34 and $59 \mathrm{~mm}^{3}$, respectively. By the end of week 22, nearly all rats in the DMH-treated groups (G1-G3) developed colorectal tumors. The tumor incidence and multiplicity were similar among groups as shown in Table 4. A trend towards the reduction of invasive tumors was observed in the group given capsaicin at $50 \mathrm{mg}$ / 
Table 1

Body weight, liver weight, food intake and serum biochemical parameters in controls and capsaicin-treated rats ${ }^{1}$.

\begin{tabular}{|c|c|c|c|c|c|c|}
\hline \multicolumn{7}{|l|}{4 weeks $(n=6)$} \\
\hline & G1 & G2 & G3 & G4 & G5 & G6 \\
\hline Parameters & DMH & DMH + CAP 5 & $\mathrm{DMH}+\mathrm{CAP} 50$ & CAP 5 & CAP 50 & Control \\
\hline Initial body weight $(\mathrm{g})$ & $232.25 \pm 19.34$ & $225.25 \pm 21.08$ & $243.75 \pm 20.65$ & $220.75 \pm 20.75$ & $222.88 \pm 24.17$ & $236.63 \pm 34.90$ \\
\hline Final body weight (g) & $299.94 \pm 21.75$ & $281.75 \pm 35.05$ & $311.88 \pm 39.95$ & $304.54 \pm 20.65$ & $307.31 \pm 27.85$ & $325.75 \pm 41.16$ \\
\hline Weight gain (g) & $67.69 \pm 10.06$ & $61.29 \pm 21.41$ & $68.13 \pm 28.22$ & $83.92 \pm 20.15$ & $89.00 \pm 17.02$ & $89.13 \pm 21.38$ \\
\hline Food intake (g/rat/day) & $19.91 \pm 4.66$ & $19.04 \pm 4.82$ & $21.50 \pm 5.29$ & $21.51 \pm 2.70$ & $21.79 \pm 6.65$ & $22.75 \pm 2.66$ \\
\hline Liver relative weight $(\mathrm{g})$ & $2.91 \pm 0.25$ & $2.99 \pm 0.20$ & $2.96 \pm 0.44$ & $2.91 \pm 0.31$ & $3.06 \pm 0.28$ & $2.75 \pm 0.07$ \\
\hline ALT (IU/L) & $99.80 \pm 28.69^{\dagger}$ & $72.80 \pm 18.77$ & $79.20 \pm 12.73$ & $47.40 \pm 9.48$ & $55.60 \pm 8.31$ & $51.20 \pm 16.34$ \\
\hline AST (IU/L) & $269.40 \pm 85.95^{\dagger}$ & $207.60 \pm 28.88$ & $262.80 \pm 99.61^{\dagger}$ & $131.80 \pm 6.05$ & $119.60 \pm 24.18$ & $126.20 \pm 28.10$ \\
\hline \multicolumn{7}{|l|}{22 weeks $(n=10)$} \\
\hline Parameters & DMH & $\mathrm{DMH}+\mathrm{CAP} 5$ & $\mathrm{DMH}+\mathrm{CAP} 50$ & CAP 5 & CAP 50 & Control \\
\hline Initial body weight ( $\mathrm{g}$ ) & $226.40 \pm 18.22$ & $223.20 \pm 21.98$ & $244.70 \pm 25.51$ & $221.57 \pm 24.08$ & $212.71 \pm 15.93$ & $241.33 \pm 28.04$ \\
\hline Final body weight (g) & $445.60 \pm 30.62$ & $449.50 \pm 51.08$ & $468.70 \pm 51.97$ & $446.00 \pm 35.02$ & $438.00 \pm 26.58$ & $467.40 \pm 34.66$ \\
\hline Weight gain $(\mathrm{g})$ & $218.22 \pm 19.88$ & $220.38 \pm 38.39$ & $221.75 \pm 37.21$ & $198.40 \pm 26.54$ & $230.00 \pm 34.91$ & $228.00 \pm 22.83$ \\
\hline Liver relative weight $(\mathrm{g})$ & $1.97 \pm 0.15$ & $2.27 \pm 0.37$ & $2.04 \pm 0.15$ & $2.21 \pm 0.28$ & $2.11 \pm 0.13$ & $2.12 \pm 0.25$ \\
\hline
\end{tabular}

${ }^{1}$ Values represent the mean \pm SD for 6-10 rats/group. Differences between groups were determined using one-way ANOVA followed by Tukey's test. 'Different from G4, G5 and G6, $p<0.0005$. ALT: alanine aminotransferase; AST: aspartate aminotransferase; DMH: 1,2-dimethylhydrazine; CAP 5 : capsaicin 5 mg/kg bw; CAP 50: capsaicin 50 mg/kg bw.

kg (G3) (Table 4). Histopathological analysis showed that most tumors were either well-differentiated tubular adenocarcinomas (Fig. 4C and D) or poorly-differentiated mucinous adenocarcinomas (Fig. 4E and F).

ACF formation.

Table 5 summarizes the effects of capsaicin on DMH-induced ACF formation. All DMH-treated animals (G1-G3) developed colon ACF 22 weeks after the last DMH administration. No ACF was observed in the control groups (G4-G6). Capsaicin at $50 \mathrm{mg} / \mathrm{kg}$ (G3) significantly reduced $(0.0008<p<0.0209)$ the number of ACF consisting of $1-3$, and $\geq 10$ crypts per focus, as well as the total number of AC and ACF (0.0209 $<p<0.0244)$, when compared to DMH-treated group (G1). Fig. 4 shows light-micrographs of normal crypts (4G) and an ACF stained with methylene blue $(4 \mathrm{H})$.

\section{Discussion}

In this study, capsaicin anti-genotoxicity, anti-proliferative and proapoptotic effects were investigated in rats, before and during DMH administration (short-term), as well as pre-neoplastic lesions and tumors 22 weeks after the last DMH injection (mid-term). The results obtained in the short-term assays show that capsaicin at $50 \mathrm{mg} / \mathrm{kg}$ suppressed DMH-induced cytotoxicity and genotoxicity, promoting anti-proliferative and pro-apoptotic responses through the expression of the genes involved in apoptosis, cell cycle suppression and cell/tissue differentiation on the colonic mucosa. In the mid-term assays, capsaicin at $50 \mathrm{mg} / \mathrm{kg}$ reduced ACF number and multiplicity.

Our findings indicate that capsaicin at $50 \mathrm{mg} / \mathrm{kg}$ decreased both DMH-induced genotoxicity in the leukocytes and fecal water genotoxicity in CaCO-2 cells. Both leukocyte and fecal water comet assay analyses demonstrate that capsaicin alone did not increase genotoxicity. Previous studies have shown that capsaicin has substantial antimutagenic and anti-genotoxic effects on different chemical mutagens (Fernández-Bedmar and Alonso-Moraga 2016; Hassan et al. 2012; Huynh and Teel 2005). Most studies on capsaicin genotoxicity and mutagenicity have used capsaicin of different levels of purity or chili extracts (Bley et al. 2012). However, some studies have reported capsaicin contamination with organic phosphates, pesticides, fusarium and aflatoxin, which can seriously affect genotoxicity assessment (Johnson

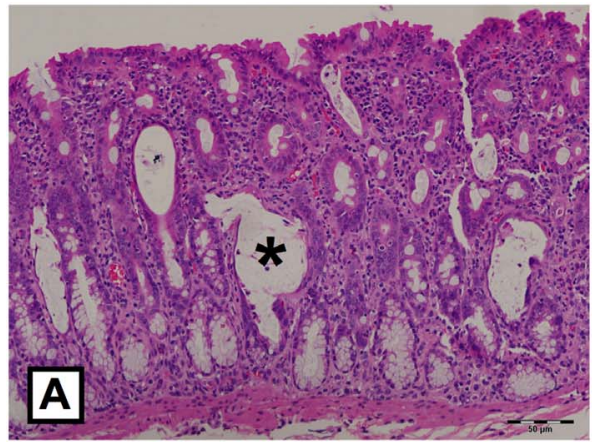

Ki-67 Immunoexpression

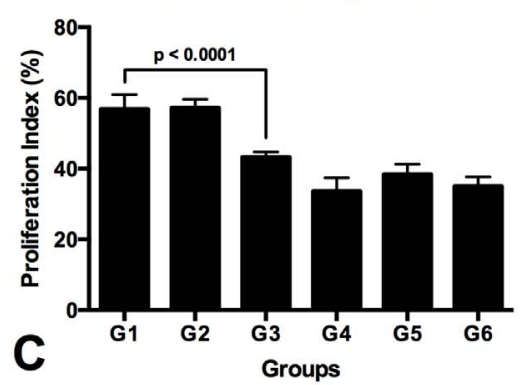

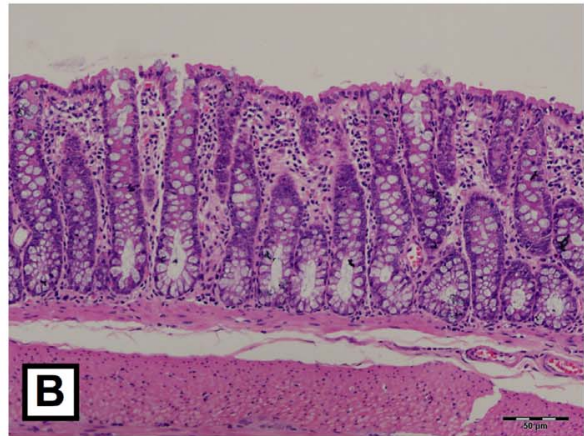

Caspase-3 Immunoexpression

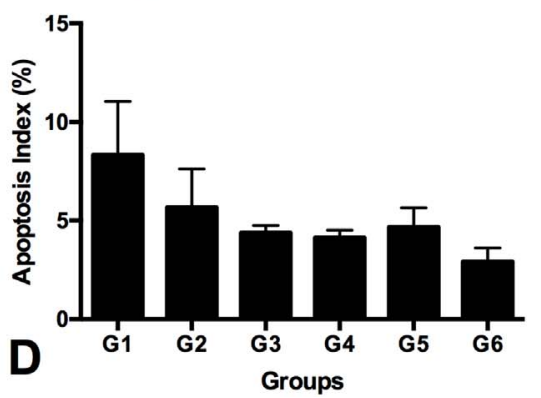

Fig. 3. Histopathology and immunohistochemistry of colonic mucosa in the short-term (4 weeks) assay (A) DMHinduced toxic lesions in the colonic mucosa, exhibiting crypt distortions (*), depletion of goblet cells, and increased apoptosis. (C) Ki-67 proliferation labeling indexes. (B) Normal histology features of the colon in control group. (D) Active caspase- 3 apoptosis labeling indexes. ${ }^{1}$ Data are presented as mean \pm SD for 6 rats/group. Differences between groups were determined using by One-way ANOVA followed by post hoc Tukey's test. G1: DMH + corn oil (capsaicin vehicle); G2: DMH + capsaicin at $5 \mathrm{mg} / \mathrm{kg}$ bw; G3: $\mathrm{DMH}+$ capsaicin at $50 \mathrm{mg} / \mathrm{kg}$ bw; G4: $\mathrm{Na}_{2}$ EDTA (DMH vehicle) + capsaicin at $5 \mathrm{mg} / \mathrm{kg}$ bw; G5: $\mathrm{Na}_{2}$ EDTA + capsaicin at $50 \mathrm{mg} / \mathrm{kg}$ bw; G6: $\mathrm{Na}_{2}$ EDTA + corn oil. S: sacrifice; DMH: 1,2-dimethylhidrazine; $\mathrm{Na}_{2}$ EDTA: disodium ethylenediamine tetraacetic acid. 
Table 2

Differential gene expression in the colon samples of capsaicin-treated rats ${ }^{1}$.

\begin{tabular}{lllll}
\hline Comparisons & Gene & Ensembl ID & Fold Change & P value \\
\hline \multirow{2}{*}{ G2 vs G1 } & Dffb & ENSRNOG00000025030 & 1.532 & 0.022 \\
& Gsk3b & ENSRNOG00000002833 & 1.627 & 0.041 \\
& Raf1 & ENSRNOG00000010153 & 1.781 & 0.021 \\
G3 vs G1 & Dffb & ENSRNOG00000025030 & 1.548 & 0.016 \\
& Casp4 & ENSRNOG00000033697 & 2.094 & 0.010 \\
& Aifm1 & ENSRNOG00000006067 & 1.689 & 0.030 \\
& Wee1 & ENSRNOG00000010017 & 1.553 & 0.006 \\
& Sp1 & ENSRNOG00000014084 & 1.769 & 0.004 \\
& Foxa-1 & ENSRNOG00000009284 & 1.761 & 0.002 \\
& Cdh1 & ENSRNOG00000020151 & 1.951 & 0,032 \\
& Smad4 & ENSRNOG00000051965 & 1.549 & 0.034 \\
& Grb2 & ENSRNOG00000037360 & 1.940 & 0.006 \\
& Raf1 & ENSRNOG00000010153 & 2.046 & 0.036 \\
& Mapk3 & ENSRNOG00000053583 & 2.229 & 0.028 \\
& Mapk14 & ENSRNOG00000000513 & 1.867 & 0.032 \\
& Nfkb1 & ENSRNOG00000023258 & 1.851 & 0.032 \\
& Stat5b & ENSRNOG00000019075 & 1.583 & 0.020 \\
& Ikbkg & ENSRNOG00000060936 & 1.786 & 0.016 \\
& Igfr1 & ENSRNOG00000014187 & 0.569 & 0.032 \\
& Akt1 & ENSRNOG00000028629 & 0.652 & 0.019 \\
& CdkN1a & ENSRNOG00000000521 & 1.933 & 0.018 \\
\hline
\end{tabular}

${ }^{1}$ Relative expression levels were determined by normalization to beta-actin (Actb), glyceraldeyde-3-phosphate dehydrogenase (Gapdh), beta-glucuronidase (Gusb) and hypoxanthine-guanine phosphoribosyltransferase (Hprt1). Experimental groups were compared using the Student's t-test. Fold change boundary of 1.5 (1.5-fold change) and a $\mathrm{P}$ value of $<0.05$ were used. G1: DMH + corn oil (capsaicin vehicle); G2: DMH + capsaicin $5 \mathrm{mg} / \mathrm{kg}$ bw; G3: DMH + capsaicin at $50 \mathrm{mg} / \mathrm{kg}$ bw; G4: $\mathrm{Na}_{2}$ EDTA (DMH vehicle) + capsaicin at $5 \mathrm{mg} / \mathrm{kg}$ bw; G5: $\mathrm{Na}_{2}$ EDTA + capsaicin at $50 \mathrm{mg} / \mathrm{kg}$ bw; G6: $\mathrm{Na}_{2}$ EDTA + corn oil. S: sacrifice; DMH: 1,2-dimethylhidrazine; $\mathrm{Na}_{2}$ EDTA: disodium ethylenediamine tetraacetic acid.

2007; Kuzma et al. 2014; Proudlock et al. 2004). Together, our results suggest that capsaicin has an anti-genotoxic effect and may inhibit the DNA damage induced by DMH, as previously demonstrated by other (De et al. 1995; Melgar-Lalanne et al. 2017; Proudlock et al. 2004).

This study showed that oral administration of capsaicin increased the expression of the genes $N F-\kappa B$ and $I k b k g$, which is a regulatory subunit of the kappaB kinase (NEMO/IKK $\gamma$ ) complex that phosphorylates and activates $N F-\kappa B$ (Salminen et al. 2012). Methyldiazonium ion is the ultimate $\mathrm{DMH}$ carcinogenic metabolite responsible for the methylation of DNA bases that induces genotoxic stress and trigger $N F-\kappa B$ activation in colonic epithelial cells (Perše and Cerar 2011; Tanwar et al. 2009). Nuclear factor kappa B (NF-kB), an important mediator of cell response to DNA damage, has been shown to facilitate cell escape from the letal effects of DNA damage, stimulate cell growth, and induce cell proliferation (Hoesel and Schmid 2013). Conversely, capsaicin also induced the expression of $N F-\kappa B$ inhbitors, such as the genes Mapk3 Mapk14, and Smad4. Mapk14, also known as p38a, is a serine/threonine stress-activated protein kinase that is activated in response to a variety of extracellular stimuli, including genotoxic stress induced by chemicals (Igea and Nebreda 2015), promoting apoptosis and $N F-\kappa B$ regulation (Gil-Araujo et al. 2014; Igea and Nebreda 2015; Olson et al. 2007). In the colon, Smad4 downregulation leads to uncontrolled cell proliferation (Dienstmann et al. 2017; Handra-Luca et al. 2011). According to our results, capsaicin $50 \mathrm{mg} / \mathrm{kg}$ suppressed Ki-67 proliferation indexes under carcinogen insult. This finding is consistent with the concomitant expression of the Mapk3, Mapk14 and Smad4 genes that are involved in the suppression of $N F-\kappa B$ activation, cell growth and proliferation (Aggarwal and Shishodia 2004; Brown et al. 2010; Qian et al. 2016).

The oral administration of capsaicin in this study markedly induced the expression of apoptosis-related genes in the colonic mucosa, including Casp4, Sp1, Aifm1 and Dffb. Capsaicin-induced apoptosis has been reported to cause ER calcium release and to increase the transcriptional activation of pro-apoptotic genes (O'Neill et al. 2012; Srivastava 2013; Thomas et al. 2011) such as Aifm, an important effector for caspase-independent cell death (Tica Sedlar et al. 2016). Aifm encodes an apoptosis-inducing factor (AIF) that functions as an oxidoreductase in the inner mitochondrial membrane (Sun et al. 2016). Upon cell death stimuli, increased cytoplasmic calcium concentration causes the disruption of the mitochondrial membrane, leading to AIF translocation to the nucleus (Daugas et al. 2000). AIF is binds to the DNA, causing chromatin condensation and DNA fragmentation regardless of caspase activation (Cregan et al. 2004). Both doses of capsaicin also increased the expression of the $D f f b$ gene. $D f f b$ encodes the active subunit of the apoptotic nuclease DNA fragmentation factor (DFF), a heterodimeric protein that triggers both DNA fragmentation and chromatin condensation during apoptosis (Samejima and Earnshaw 2005). DNA fragmentation factors such as DFF, greatly contribute to genomic stability by ensuring the removal of DNA-damaged cells (Ohyashiki et al. 2017; Yan et al. 2006).

The functional enrichment analysis revealed that capsaicin oral administration up-regulated the expression of the genes associated with tissue development and cell differentiation. This finding may be the molecular clue to the chemopreventive effect of capsaicin on DMH-induced colonic mucosa toxicity. Histopathological analysis showed that DMH exposure induced apoptosis, loss of goblet cell differentiation and crypt distortions on the colonic mucosa. Indeed, tissue loss is replaced via compensatory cell proliferation following chemical insult and significant cell death, (Meier and Banreti 2016). Moreover, capsaicin oral administration has been shown to modulate DMH-induced cell proliferation by increasing the expression of anti-proliferative and cell differentiation genes.

Our findings indicate an increased expression of the Foxa1 and Cdh1 genes in the group receiving capsaicin at $50 \mathrm{mg} / \mathrm{kg}$. This is consistent with a cellular response towards cell differentiation because Foxa1 is known to play a pivotal role in postnatal development and cell differentiation (Bernardo and Keri 2012). In the colon, Foxa1 modulates the secretory activity and controls the differentiation of goblet cells (Ye and Kaestner 2009). Another important gene associated with cell differentiation is Cdh1. Cdh1 encodes E-cadherin, a cell-cell adhesion glycoprotein that plays a leading role in the suppression of cell growth and

Table 3

Significantly enriched gene ontology (GO) annotated terms in up-regulated genes of rats treated with capsaicin at $50 \mathrm{mg} / \mathrm{kg}$ (G3).

\begin{tabular}{|c|c|c|c|c|}
\hline S. No. & GO term & Fold Enrichment & No. of Genes & $P$ value \\
\hline 1 & GO:0070887 - cellular response to chemical stimulus & 7.68 & 13 & 0.00002 \\
\hline 2 & GO:0033554 - cellular response to stress & 9.10 & 10 & 0.00016 \\
\hline 3 & GO:0006915 - apoptotic process & 17.43 & 9 & 0.00004 \\
\hline 4 & GO:0050790 - regulation of catalytic activity & 7.00 & 11 & 0.00310 \\
\hline 5 & GO:0070848 - response to growth factor & 23.13 & 9 & 0.00001 \\
\hline 6 & GO:0080134 - regulation of response to stress & 9.02 & 8 & 0.00812 \\
\hline 7 & GO:0006974 - cellular response to DNA damage & 13.32 & 6 & 0.02930 \\
\hline 8 & GO:0010941 - regulation of cell death & 9.30 & 11 & 0.00018 \\
\hline 9 & GO:0009888 - tissue development & 7.30 & 9 & 0.00760 \\
\hline 10 & GO:0030154 - cell differentiation & 5.57 & 14 & 0.00015 \\
\hline
\end{tabular}




\section{Tumor Volume}

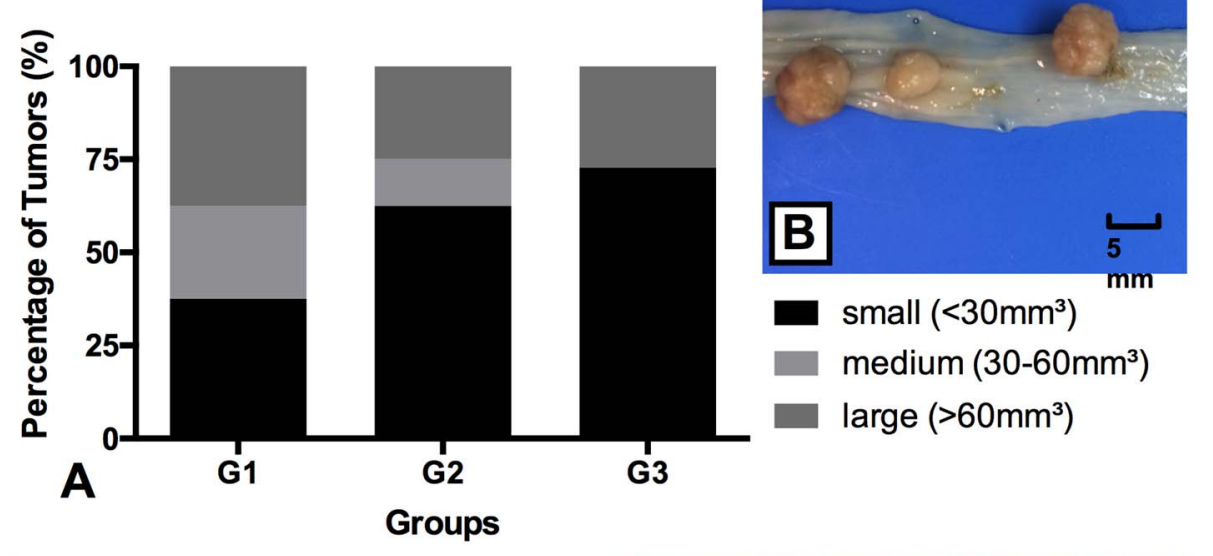

Figure 4. Tumor volume, histopathology and aberrant crypt foci (ACF) induced by DMH in control and capsaicintreated rats. (A) Percentage of small, medium and large tumor volumes in the DMH-treated groups. (B) Macroscopic image of colon carcinomas in the medial region of the colonic mucosa. (C) Sessile, exophytic tumor mass arising from the colonic mucosa. (D) Tubular adenocarcinoma. (E) Endophytic tumor with extensive submucosal spread. (F) Mucinous adenocarcinoma with signet ring cells. (G) Normal-appearing colonic mucosa stained with methylene blue. (H) Methylene blue-stained aberrant crypt foci (ACF) consisting of seven large, elliptical crypts with thickened epithelial cell lining and increased pericryptal space. G1: DMH + corn oil (capsaicin vehicle); G2: DMH + capsaicin at $5 \mathrm{mg} / \mathrm{kg}$ bw; G3: DMH + capsaicin at $50 \mathrm{mg} / \mathrm{kg}$ bw; DMH: 1,2-dimethylhidrazine. (For interpretation of the references to colour in this figure legend, the reader is referred to the web version of this article.)
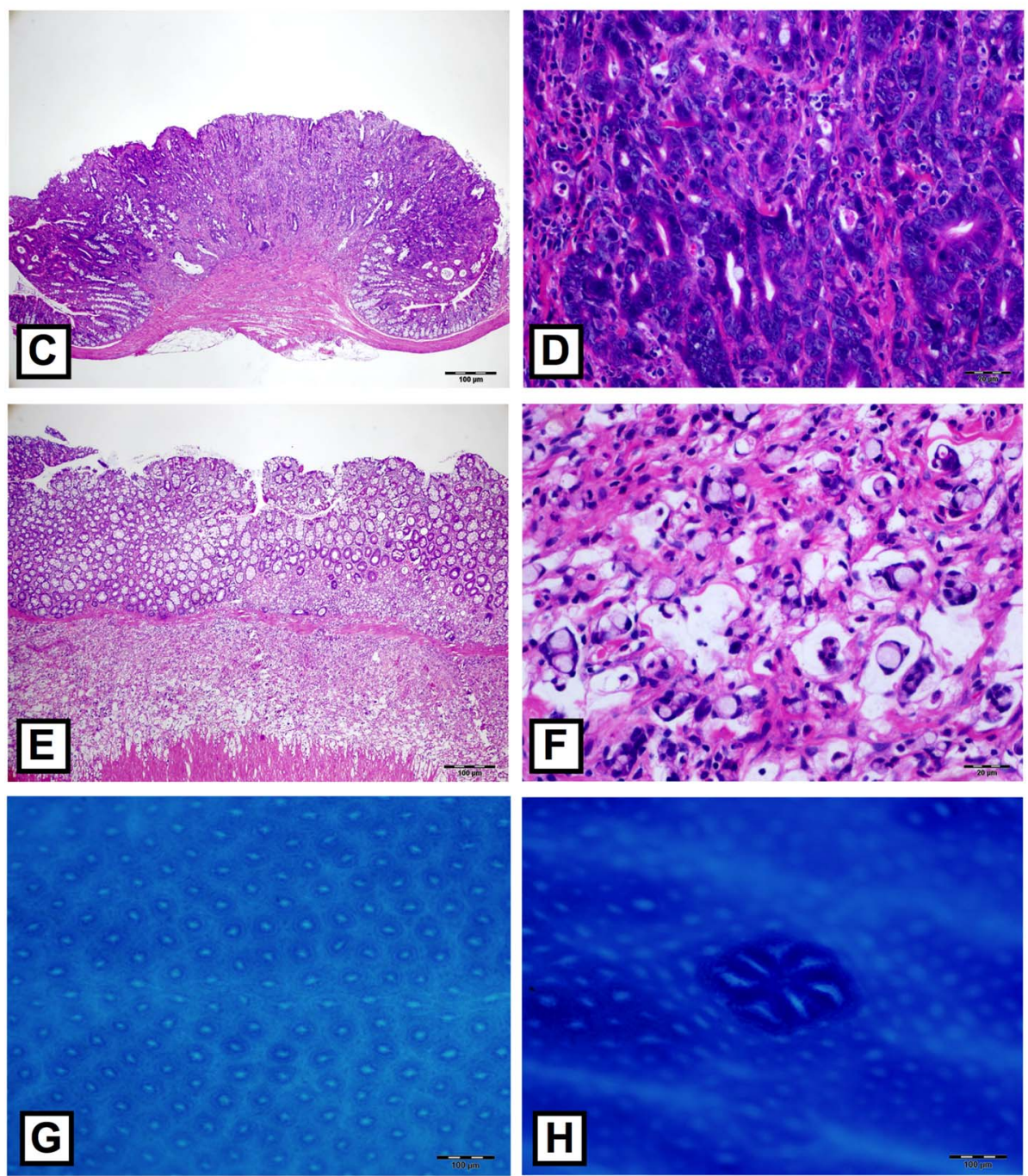

invasion. E-cadherin loss is an integral step in the epithelial-mesenchymal transition (EMT), that is associated with tumor progression, invasion and metastasis in CRC (Heerboth et al. 2015; Yun et al. 2014). Conversely, increased E-cadherin expression has been shown to decrease ERK1/2 phosphorylation, suggesting a suppressor role in the Kras oncogenic pathway (Satow et al. 2014).

Our results show that capsaicin failed to modulate the expression of the genes involved in liver oxidative metabolism, pro- and anti-oxidative activity, cell proliferation, DNA damage, DNA repair and apoptosis (Supplementary Data, SM2). Although capsaicin has been hypothesized to interact with a number of cytochrome P450 enzymes (CYPs) in the liver (Zhang et al. 2012), studies have demonstrated that the in vitro inhibition of cytochrome P450 enzymes by capsaicin can be observed only at very high doses, suggesting that capsaicin inhibitory effect on 
Table 4

Incidence and multiplicity of various tumors induced by DMH in control and capsaicin-treated rats ${ }^{1}$.

\begin{tabular}{|c|c|c|c|c|c|c|c|}
\hline \multicolumn{2}{|c|}{ Groups/Treatments } & \multirow{2}{*}{ Number of animals } & \multirow[t]{2}{*}{ Number of tumors } & \multirow[t]{2}{*}{ Multiplicity } & \multirow[b]{2}{*}{ Tubular Adenocarcinoma } & \multicolumn{2}{|l|}{ Incidence (\%) } \\
\hline & & & & & & Carcinoma in situ & Mucinous Adenocarcinoma \\
\hline (G1) & $\mathrm{DMH}$ & 10 & 15 & $1.67 \pm 1.32$ & 72.72 & 9.10 & 18.18 \\
\hline (G2) & $\mathrm{DMH}+\mathrm{CAP} 5$ & 10 & 11 & $2.20 \pm 0.84$ & 61.53 & 15.40 & 23.07 \\
\hline (G3) & $\mathrm{DMH}+\mathrm{CAP} 50$ & 10 & 13 & $1.86 \pm 1.07$ & 71.43 & 28.57 & 0 \\
\hline
\end{tabular}

${ }^{1}$ Multiplicity is the average number of all tumors in each tumor-bearing mouse. Multiplicity values are represented as the mean \pm SD. Tumor incidence is the percentage of mice

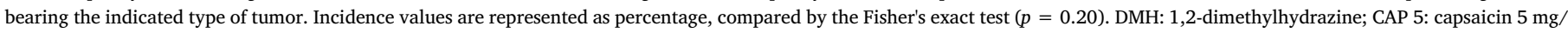
$\mathrm{kg}$ bw; CAP 50: capsaicin $50 \mathrm{mg} / \mathrm{kg}$ bw.

Table 5

Inhibitory effects of capsaicin treatment on the number of aberrant crypt foci pre-neoplastic lesions ${ }^{1}$.

\begin{tabular}{|c|c|c|c|c|c|c|c|c|}
\hline \multicolumn{2}{|c|}{ Groups/Treatments ${ }^{2}$} & \multirow[t]{2}{*}{ No. of animals } & \multicolumn{3}{|l|}{ Number of ACF } & \multicolumn{3}{|l|}{ Total Number } \\
\hline & & & $1-3$ crypts & 4-9 crypts & $\geq 10$ crypts & $\mathrm{AC}^{3}$ & ACF & $\mathrm{AC} / \mathrm{ACF}$ \\
\hline (G1) & $\mathrm{DMH}$ & 10 & $170.10 \pm 55.47$ & $110.70 \pm 43.47$ & $17.90 \pm 13.54$ & $1230.00 \pm 375.74$ & $311.30 \pm 57.80$ & $3.91 \pm 0.71$ \\
\hline (G2) & $\mathrm{DMH}+\mathrm{CAP} 5$ & 10 & $156.70 \pm 54.05$ & $140.10 \pm 39.63$ & $13.40 \pm 7.99$ & $1260.60 \pm 370.90$ & $309.90 \pm 89.91$ & $4.06 \pm 0.35$ \\
\hline (G3) & $\mathrm{DMH}+\mathrm{CAP} 50$ & 10 & $106.90 \pm 35.04^{\mathrm{a}}$ & $75.00 \pm 18.98^{b}$ & $2.60 \pm 1.65^{\mathbf{a}, \mathbf{b}}$ & $660.60 \pm 147.52^{\mathbf{a}, \mathbf{b}}$ & $184.60 \pm 44.92^{\mathbf{a}, \mathbf{b}}$ & $3.62 \pm 0.36$ \\
\hline (G4) & CAP 5 & 7 & 0 & 0 & 0 & 0 & 0 & 0 \\
\hline (G5) & CAP 50 & 7 & 0 & 0 & 0 & 0 & 0 & 0 \\
\hline (G6) & Control & 7 & 0 & 0 & 0 & 0 & 0 & 0 \\
\hline
\end{tabular}

${ }^{1}$ Values represent the mean \pm SD for 7-10 rats/group. Differences between groups were determined using one-way ANOVA followed by Tukey's test. ${ }^{\mathrm{a} D i f f e r e n t}$ from G1,

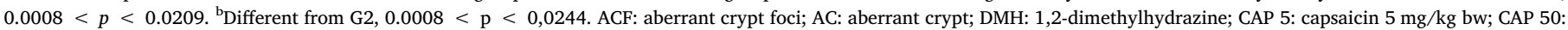
capsaicin $50 \mathrm{mg} / \mathrm{kg}$.

drug metabolism is minimal (Chanda et al. 2008; Babbar et al. 2010). Thus, the protective effects of the capsaicin regimen adopted did not affect DMH metabolism via either CYP induction or inhibition.

In this study, capsaicin reduced total AC and ACF development, as well as ACF multiplicity, in agreement with other report (Yoshitani et al. 2001). ACF have been adopted as biomarkers for the screening of preventive agents and has been correlated with tumor growth in different models of colon carcinogenesis (Rodrigues et al. 2002; Wargovich et al. 2010). ACF with a high number of aberrant crypts are more likely to progress to adenomas and adenocarcinomas during colorectal carcinogenesis (Takahashi et al. 2012). In this regard, we observed that capsaicin at $50 \mathrm{mg} / \mathrm{kg}$ trend to reduce the tumor size as well as the number of invasive tumors in the colon. Despite these differences, however, tumor incidence and multiplicity rates were similar in the capsaicin-treated groups. These results demonstrate that capsaicin has a weak protective effect for colon tumors induced by DMH. Therefore, chemopreventive potential of capsaicin was evidenced only shortly after DMH administration and latter on ACF development.

\section{Conclusion}

Capsaicin administration reduced cell proliferation as well as modulated the genes involved in cell proliferation, apoptosis, tissue development and differentiation, suppressing ACF development. Thus, our results indicate that capsaicin may have a chemopreventive effect against DMH-induced colorectal carcinogenesis.

\section{Acknowledgments}

This work was supported by the Sao Paulo Research Foundation (FAPESP) and the National Council for Scientific and Technological Development (CNPq) under grants 2014/21951-6, 2014/24762-0 and 304128/2015-5, respectively. We thank Paulo Cesar Georgete for technical support and Mariza Branco da Silva for English editing of this paper.

\section{Author contributions}

All authors contributed equally to this work.

\section{Conflicts of interest}

The authors declare no conflict of interest.

Supplementary data.

Supplementary material 1 .

Supplementary material 2.

Supplementary material 3 .

Supplementary material 4.

\section{References}

Aggarwal, B.B., Shishodia, S., 2004. Suppression of the nuclear factor-кB activation pathway by spice-derived phytochemicals: reasoning for seasoning. Ann. N. Y. Acad. Sci. 1030, 434-441. http://dx.doi.org/10.1196/annals.1329.054.

Agrawal, R.C., Wiessler, M., Hecker, E., Bhide, S.V., 1986. Tumour-promoting effect of chilli extract in BALB/c mice. Int. J. Cancer 38, 689-695.

Ashburner, M., Ball, C.A., Blake, J.A., Botstein, D., Butler, H., Cherry, J.M., Davis, A.P., Dolinski, K., Dwight, S.S., Eppig, J.T., Harris, M.A., Hill, D.P., Issel-Tarver, L., Kasarskis, A., Lewis, S., Matese, J.C., Richardson, J.E., Ringwald, M., Rubin, G.M., Sherlock, G., 2000. Gene ontology: tool for the unification of biology. Nat. Genet. 25, 25-29. http://dx.doi.org/10.1038/75556.

Babbar, S., Chanda, S., Bley, K., 2010. Inhibition and induction of human cytochrome P450 enzymes in vitro by capsaicin. Xenobiotica 40, 807-816. http://dx.doi.org/10. 3109/00498254.2010.520044.

Baena, R., Salinas, P., 2015. Diet and colorectal cancer. Maturitas 80, 258-264. http://dx doi.org/10.1016/j.maturitas.2014.12.017.

Bernardo, G.M., Keri, R.A., 2012. FOXA1: a transcription factor with parallel functions in development and cancer. Biosci. Rep. 32, 113-130. http://dx.doi.org/10.1042/ BSR20110046.

Bird, R.P., 1987. Observation and quantification of aberrant crypts in the murine colon treated with a colon carcinogen: preliminary findings. Cancer Lett. 37, 147-151.

Bley, K., Boorman, G., Mohammad, B., McKenzie, D., Babbar, S., 2012. A comprehensive review of the carcinogenic and Anticarcinogenic potential of capsaicin. Toxicol. Pathol. 40, 847-873. http://dx.doi.org/10.1177/0192623312444471.

Bode, A.M., Dong, Z., 2011. The two faces of capsaicin. Cancer Res. 71, 2809-2814. http://dx.doi.org/10.1158/0008-5472.CAN-10-3756.

Bosland, P.W., Votava, E.J., Votava, E.M., 2012. Peppers: Vegetable and Spice Capsicums. CABI.

Brown, K.C., Witte, T.R., Hardman, W.E., Luo, H., Chen, Y.C., Carpenter, A.B., Lau, J.K., Dasgupta, P., 2010. Capsaicin displays anti-proliferative activity against human small 
cell lung cancer in cell culture and nude mice models via the E2F pathway. PLoS One 5. http://dx.doi.org/10.1371/journal.pone.0010243.

Bustin, S.A., Benes, V., Garson, J.A., Hellemans, J., Huggett, J., Kubista, M., Mueller, R., Nolan, T., Pfaffl, M.W., Shipley, G.L., Vandesompele, J., Wittwer, C.T., 2009. The MIQE guidelines: minimum information for publication of quantitative real-time PCR experiments. Clin. Chem. 55, 611-622. http://dx.doi.org/10.1373/clinchem.2008. 112797.

Carr, P.R., Walter, V., Brenner, H., Hoffmeister, M., 2016. Meat subtypes and their association with colorectal cancer: systematic review and meta-analysis. Int. J. Cancer 138, 293-302. http://dx.doi.org/10.1002/ijc.29423.

Chanda, S., Bashir, M., Babbar, S., Koganti, A., Bley, K., 2008. In vitro hepatic and skin metabolism of capsaicin. Drug Metab. Dispos. Biol. Fate Chem. 36, 670-675. http:// dx.doi.org/10.1124/dmd.107.019240.

Corpet, D.E., Taché, S., 2002. Most effective colon cancer chemopreventive agents in rats: a systematic review of aberrant crypt foci and tumor data, ranked by potency. Nutr. Cancer 43, 1-21.

Cregan, S.P., Dawson, V.L., Slack, R.S., 2004. Role of AIF in caspase-dependent and caspase-independent cell death. Oncogene 23, 2785-2796. http://dx.doi.org/10. 1038/sj.onc.1207517.

Dahham, S.S., Majid, A.M.A., 2016. The impact of life style and nutritional components in primary prevention of colorectal cancer. J. Appl. Pharm. Sci. 6, 237-244.

Daugas, E., Nochy, D., Ravagnan, L., Loeffler, M., Susin, S.A., Zamzami, N., Kroemer, G., 2000. Apoptosis-inducing factor (AIF): a ubiquitous mitochondrial oxidoreductase involved in apoptosis. FEBS Lett. 476, 118-123. http://dx.doi.org/10.1016/S00145793(00)01731-2.

De, A.K., Agarwal, K., Mukherjee, A., Sengupta, D., 1995. Inhibition by capsaicin against cyclophosphamide-induced clastogenicity and DNA damage in mice. Mutat. Res. 335, 253-258.

Díaz Barriga Arceo, S., Madrigal-Bujaidar, E., Calderón Montellano, E., Ramírez Herrera, L., Díaz García, B.D., 1995. Genotoxic effects produced by capsaicin in mouse during subchronic treatment. Mutat. Res. 345, 105-109.

Díaz-Laviada, I., 2010. Effect of capsaicin on prostate cancer cells. Future Oncol. Lond. Engl. 6, 1545-1550. http://dx.doi.org/10.2217/fon.10.117.

Dienstmann, R., Vermeulen, L., Guinney, J., Kopetz, S., Tejpar, S., Tabernero, J., 2017. Consensus molecular subtypes and the evolution of precision medicine in colorectal cancer. Nat. Rev. Cancer advance online publication. http://dx.doi.org/10.1038/nrc. 2016.126.

Fattori, V., Hohmann, M.S.N., Rossaneis, A.C., Pinho-Ribeiro, F.A., Verri, W.A., 2016. Capsaicin: current understanding of its mechanisms and therapy of pain and other pre-clinical and clinical uses. Molecules 21, 844. http://dx.doi.org/10.3390/ molecules 21070844

Ferlay, J., Soerjomataram, I., Dikshit, R., Eser, S., Mathers, C., Rebelo, M., Parkin, D.M., Forman, D., Bray, F., 2015. Cancer incidence and mortality worldwide: sources, methods and major patterns in GLOBOCAN 2012. Int. J. Cancer 136, E359-386. http://dx.doi.org/10.1002/ijc.29210.

Fernández-Bedmar, Z., Alonso-Moraga, A., 2016. vivo and in vitro evaluation for nutraceutical purposes of capsaicin, capsanthin, lutein and four pepper varieties. Food Chem. Toxicol. 98, Part B 89-99. http://dx.doi.org/10.1016/j.fct.2016.10.011.

Garufi, A., Pistritto, G., Cirone, M., D'Orazi, G., 2016. Reactivation of mutant p53 by capsaicin, the major constituent of peppers. J. Exp. Clin. Cancer Res. CR 35, 136. http://dx.doi.org/10.1186/s13046-016-0417-9.

Gil-Araujo, B., Toledo Lobo, M.-V., Gutiérrez-Salmerón, M., Gutiérrez-Pitalúa, J., Ropero, S., Angulo, J.C., Chiloeches, A., Lasa, M., 2014. Dual specificity phosphatase 1 expression inversely correlates with NF-KB activity and expression in prostate cancer and promotes apoptosis through a p38 MAPK dependent mechanism. Mol. Oncol. 8, 27-38. http://dx.doi.org/10.1016/j.molonc.2013.08.012.

Gingras, D., Béliveau, R., 2011. Colorectal cancer prevention through dietary and lifestyle modifications. Cancer Microenviron. 4, 133-139. http://dx.doi.org/10.1007/ s12307-010-0060-5.

Handra-Luca, A., Olschwang, S., Fléjou, J.-F., 2011. SMAD4 protein expression and cell proliferation in colorectal adenocarcinomas. Virchows arch. Int. J. Pathol. 459, 511-519. http://dx.doi.org/10.1007/s00428-011-1152-4.

Hassan, M.H., Edfawy, M., Mansour, A., Hamed, A.-A., 2012. Antioxidant and antiapoptotic effects of capsaicin against carbon tetrachloride-induced hepatotoxicity in rats. Toxicol. Ind. Health 28, 428-438. http://dx.doi.org/10.1177/ 0748233711413801.

Heerboth, S., Housman, G., Leary, M., Longacre, M., Byler, S., Lapinska, K., Willbanks, A., Sarkar, S., 2015. EMT and tumor metastasis. Clin. Transl. Med. 4, 6. http://dx.doi. org/10.1186/s40169-015-0048-3.

Heiser, C.B., Smith, P.G., 1953. The cultivated capsicum peppers. Econ. Bot. 7, 214-227. http://dx.doi.org/10.1007/BF02984948.

Hoesel, B., Schmid, J.A., 2013. The complexity of NF-кB signaling in inflammation and cancer. Mol. Cancer 12, 86. http://dx.doi.org/10.1186/1476-4598-12-86.

Hou, N., Huo, D., Dignam, J.J., 2013. Prevention of colorectal cancer and dietary management. Chin. Clin. Oncol. 2, 13. http://dx.doi.org/10.3978/j.issn.2304-3865.2013 04.03.

Huynh, H.T., Teel, R.W., 2005. Vitro Antimutagenicity of Capsaicin toward Heterocyclic Amines in Salmonella Typhimurium Strain TA98. Anticancer Res. Vol. 25. pp. $117-120$

Igea, A., Nebreda, A.R., 2015. The stress kinase p38 $\alpha$ as a target for cancer therapy. Cancer Res. 75, 3997-4002. http://dx.doi.org/10.1158/0008-5472.CAN-15-0173.

Johnson, W.J., 2007. Final report on the safety assessment of capsicum Annuum extract, capsicum Annuum fruit extract, capsicum Annuum resin, capsicum Annuum frui powder, capsicum Frutescens fruit, capsicum Frutescens fruit extract, capsicum Frutescens resin, and capsaicin. Int. J. Toxicol. 26, 3-106. http://dx.doi.org/10. $1080 / 10915810601163939$.
Kamangar, F., Dores, G.M., Anderson, W.F., 2006. Patterns of cancer incidence, mortality, and prevalence across five continents: defining priorities to reduce cancer disparities in different geographic regions of the world. J. Clin. Oncol. 24, 2137-2150. http:// dx.doi.org/10.1200/JCO.2005.05.2308.

Kantar, M.B., Anderson, J.E., Lucht, S.A., Mercer, K., Bernau, V., Case, K.A., Le, N.C., Frederiksen, M.K., DeKeyser, H.C., Wong, Z.-Z., Hastings, J.C., Baumler, D.J., 2016 Vitamin variation in capsicum Spp. provides opportunities to improve nutritional value of human diets. PLoS One 11, e0161464. http://dx.doi.org/10.1371/journal. pone.0161464.

Klinder, A., Karlsson, P.C., Clune, Y., Hughes, R., Glei, M., Rafter, J.J., Rowland, I., Collins, J.K., Pool-Zobel, B.L., 2007. Fecal water as a non-invasive biomarker in nutritional intervention: comparison of preparation methods and refinement of different endpoints. Nutr. Cancer 57, 158-167. http://dx.doi.org/10.1080/ 01635580701274848.

Kuzma, M., Past, T., Mozsik, G., Perjesi, P., 2014. Pharmacobotanical analysis and regulatory qualification of Capsicum fruits and Capsicum extracts. A survey. doi:https:// doi.org/10.5772/58812.

Lau, J.K., Brown, K.C., Dom, A.M., Witte, T.R., Thornhill, B.A., Crabtree, C.M., Perry, H.E., Brown, J.M., Ball, J.G., Creel, R.G., Damron, C.L., Rollyson, W.D., Stevenson, C.D., Hardman, W.E., Valentovic, M.A., Carpenter, A.B., Dasgupta, P., 2014. Capsaicin induces apoptosis in human small cell lung cancer via the TRPV6 receptor and the calpain pathway. Apoptosis Int. J. Program. Cell Death 19, 1190-1201. http://dx.doi.org/10.1007/s10495-014-1007-y.

Lee, B.M., Park, K.-K., 2003. Beneficial and adverse effects of chemopreventive agents. Mutat. Res. 523-524, 265-278.

Liu, R.H., 2013. Health-promoting components of fruits and vegetables in the diet. Adv. Nutr. Int. Rev. J. 4, 384S-392S. http://dx.doi.org/10.3945/an.112.003517.

Liu, Z., Zhu, P., Tao, Y., Shen, C., Wang, S., Zhao, L., Wu, H., Fan, F., Lin, C., Chen, C., Zhu, Z., Wei, Z., Sun, L., Liu, Y., Wang, A., Lu, Y., 2015. Cancer-promoting effect of capsaicin on DMBA/TPA-induced skin tumorigenesis by modulating inflammation, Erk and p38 in mice. Food Chem. Toxicol. 81, 1-8. http://dx.doi.org/10.1016/j.fct. 2015.04.002.

Meier, P., Banreti, A., 2016. Tissue repair: how to inflame your Neighbours. Curr. Biol. 26, R192-R194. http://dx.doi.org/10.1016/j.cub.2016.01.033.

Melgar-Lalanne, G., Hernández-Álvarez, A.J., Jiménez-Fernández, M., Azuara, E., 2017. Oleoresins from capsicum spp.: extraction methods and bioactivity. Food Bioprocess Technol. 10, 51-76. http://dx.doi.org/10.1007/s11947-016-1793-z.

Nandhakumar, S., Parasuraman, S., Shanmugam, M.M., Rao, K.R., Chand, P., Bhat, B.V., 2011. Evaluation of DNA damage using single-cell gel electrophoresis (comet assay). J. Pharmacol. Pharmacother. 2, 107-111. http://dx.doi.org/10.4103/0976-500X. 81903.

Nolte, T., Brander-Weber, P., Dangler, C., Deschl, U., Elwell, M.R., Greaves, P., Hailey, R., Leach, M.W., Pandiri, A.R., Rogers, A., Shackelford, C.C., Spencer, A., Tanaka, T., Ward, J.M., 2016. Nonproliferative and proliferative lesions of the gastrointestina tract, pancreas and salivary glands of the rat and mouse. J. Toxicol. Pathol. 29, 1S-125S. http://dx.doi.org/10.1293/tox.29.1S.

O'Neill, J., Brock, C., Olesen, A.E., Andresen, T., Nilsson, M., Dickenson, A.H., 2012. Unravelling the mystery of capsaicin: a tool to understand and treat pain. Pharmacol. Rev. 64, 939-971. http://dx.doi.org/10.1124/pr.112.006163.

Ohyashiki, K., Kuroda, M., Ohyashiki, J.H., 2017. Chromosomes and Chromosomal Instability in Human Cancer. In: Coleman, W.B., Tsongalis, G.J. (Eds.), The Molecular Basis of Human Cancer. Springer New York, pp. 241-262. http://dx.doi.org/10. 1007/978-1-59745-458-2_15.

Olson, C.M., Hedrick, M.N., Izadi, H., Bates, T.C., Olivera, E.R., Anguita, J., 2007. p38 mitogen-activated protein kinase controls NF-kappaB transcriptional activation and tumor necrosis factor alpha production through RelA phosphorylation mediated by mitogen- and stress-activated protein kinase 1 in response to Borrelia burgdorferi antigens. Infect. Immun. 75, 270-277. http://dx.doi.org/10.1128/IAI.01412-06.

Perše, M., Cerar, A., 2011. Morphological and molecular alterations in 1,2 Dimethylhydrazine and Azoxymethane induced colon carcinogenesis in rats. $J$ Biomed Biotechnol 2011. http://dx.doi.org/10.1155/2011/473964.

Proudlock, R., Thompson, C., Longstaff, E., 2004. Examination of the potential genotoxicity of pure capsaicin in bacterial mutation, chromosome aberration, and rodent micronucleus tests. Environ. Mol. Mutagen. 44, 441-447. http://dx.doi.org/10.1002/ em. 20072

Qian, K., Wang, G., Cao, R., Liu, T., Qian, G., Guan, X., Guo, Z., Xiao, Y., Wang, X., 2016. Capsaicin suppresses cell proliferation, induces cell cycle arrest and ROS production in bladder cancer cells through FOXO3a-mediated pathways. Mol. Basel Switz. 21. http://dx.doi.org/10.3390/molecules21101406.

Rodrigues, M. a. M., Silva, L. a. G., Salvadori, D.M.F., de Camargo, J.L.V., Montenegro, M. R., 2002. Aberrant crypt foci and colon cancer: comparison between a short- and medium-term bioassay for colon carcinogenesis using dimethylhydrazine in Wistar rats. Braz. J. Med. Biol. Res. 35, 351-355. doi:https://doi.org/10.1590/S0100879X2002000300010.

Rubio, C.A., 2017. Corrupted colonic crypt fission in carcinogen-treated rats. PLoS One 12. http://dx.doi.org/10.1371/journal.pone.0172824.

Saito, A., Yamamoto, M., 1996. Acute oral toxicity of capsaicin in mice and rats. J. Toxicol. Sci. 21, 195-200.

Sales, N.M.R., Pelegrini, P.B., Goersch, M.C., 2014. Nutrigenomics: definitions and advances of this new science. J. Nutr. Metab. 2014, e202759. http://dx.doi.org/10. $1155 / 2014 / 202759$.

Salminen, A., Kauppinen, A., Kaarniranta, K., 2012. Emerging role of NF- $\kappa$ B signaling in the induction of senescence-associated secretory phenotype (SASP). Cell. Signal. 24, 835-845. http://dx.doi.org/10.1016/j.cellsig.2011.12.006.

Samejima, K., Earnshaw, W.C., 2005. Trashing the genome: the role of nucleases during apoptosis. Nat. Rev. Mol. Cell Biol. 6, 677-688. http://dx.doi.org/10.1038/nrm1715. 
Satow, R., Hirano, T., Batori, R., Nakamura, T., Murayama, Y., Fukami, K., 2014. Phospholipase $\mathrm{C} \delta 1$ induces E-cadherin expression and suppresses malignancy in colorectal cancer cells. Proc. Natl. Acad. Sci. U. S. A. 111, 13505-13510. http://dx. doi.org/10.1073/pnas.1405374111.

Schiavon, G., Ruggiero, A., Schöffski, P., van der Holt, B., Bekers, D.J., Eechoute, K., Vandecaveye, V., Krestin, G.P., Verweij, J., Sleijfer, S., Mathijssen, R.H.J., 2012. Tumor volume as an alternative response measurement for imatinib treated GIST patients. PLoS One 7, e48372. http://dx.doi.org/10.1371/journal.pone.0048372.

Srivastava, S.K., 2013. Role of Capsaicin in Oxidative Stress and Cancer. (Springer Science \& Business Media).

Sun, H., Yang, S., Li, J., Zhang, Y., Gao, D., Zhao, S., 2016. Caspase-independent cell death mediated by apoptosis-inducing factor (AIF) nuclear translocation is involved in ionizing radiation induced HepG2 cell death. Biochem. Biophys. Res. Commun. 472, 137-143. http://dx.doi.org/10.1016/j.bbrc.2016.02.082.

Takahashi, H., Yamada, E., Ohkubo, H., Sakai, E., Higurashi, T., Uchiyama, T., Hosono, K., Endo, H., Nakajima, A., 2012. Relationship of human rectal aberrant crypt foci and formation of colorectal polyp: one-year following up after polypectomy. World J. Gastrointest. Endosc. 4, 561-564. http://dx.doi.org/10.4253/wjge.v4.i12.561.

Tanwar, L., Vaish, V., Sanyal, S.N., 2009. Chemoprevention of 1,2-DimethylhydrazineInduced Colon Carcinogenesis by a Non-steroidal Anti-Inflammatory Drug, Etoricoxib. In: Rats: Inhibition of Nuclear Factor kappaB. Asian Pac. J. Cancer Prev. APJCP 10, pp. 1141-1146.

Thomas, K.C., Ethirajan, M., Shahrokh, K., Sun, H., Lee, J., Cheatham, T.E., Yost, G.S., Reilly, C.A., 2011. Structure-activity relationship of capsaicin analogs and transient receptor potential Vanilloid 1-mediated human lung epithelial cell toxicity. J. Pharmacol. Exp. Ther. 337, 400-410. http://dx.doi.org/10.1124/jpet.110.178491.

Tica Sedlar, I., Petricevic, J., Saraga-Babic, M., Pintaric, I., Vukojevic, K., 2016. Apoptotic pathways and stemness in the colorectal epithelium and lamina propria mucosae during the human embryogenesis and carcinogenesis. Acta Histochem. 118, 693-703. http://dx.doi.org/10.1016/j.acthis.2016.08.004.

Torre, L.A., Bray, F., Siegel, R.L., Ferlay, J., Lortet-Tieulent, J., Jemal, A., 2015. Global cancer statistics, 2012. CA Cancer J. Clin. 65, 87-108. http://dx.doi.org/10.3322/ caac. 21262.

Wargovich, M.J., Brown, V.R., Morris, J., 2010. Aberrant crypt foci: the case for inclusion as a biomarker for colon cancer. Cancers 2, 1705-1716. http://dx.doi.org/10.3390/ cancers2031705.

Yan, B., Wang, H., Peng, Y., Hu, Y., Wang, H., Zhang, X., Chen, Q., Bedford, J.S., Dewhirst, M.W., Li, C.-Y., 2006. A unique role of the DNA fragmentation factor in maintaining genomic stability. Proc. Natl. Acad. Sci. 103, 1504-1509. http://dx.doi. org/10.1073/pnas.0507779103.

Ye, D.Z., Kaestner, K.H., 2009. Foxa1 and Foxa2 control the differentiation of goblet and Enteroendocrine L- and D-cells in mice. Gastroenterology 137, 2052-2062. http://dx. doi.org/10.1053/j.gastro.2009.08.059.

Yoshitani, S.I., Tanaka, T., Kohno, H., Takashima, S., 2001. Chemoprevention of azoxymethane-induced rat colon carcinogenesis by dietary capsaicin and rotenone. Int. J. Oncol. 19, 929-939.

Yun, J.-A., Kim, S.-H., Hong, H.K., Yun, S.H., Kim, H.C., Chun, H.-K., Cho, Y.B., Lee, W.Y., 2014. Loss of E-cadherin expression is associated with a poor prognosis in stage III colorectal cancer. Oncology 86, 318-328. http://dx.doi.org/10.1159/000360794.

Zhang, Q.-H., Hu, J.-P., Wang, B.-L., Li, Y., 2012. Effects of capsaicin and dihydrocapsaicin on human and rat liver microsomal CYP450 enzyme activities in vitro and in vivo. J. Asian Nat. Prod. Res. 14, 382-395. http://dx.doi.org/10.1080/ 10286020.2012 .656605 . 